\title{
Person-Environment Fit Perceptions and Satisfaction at Work
}

\author{
KAMARUL ZAMAN AHMAD \& MAISARAH MAT KHAIRUDDIN \\ Faculty of Business and Accountancy \\ University Malaya
}

\begin{abstract}
This study aims to fulfil two literature gaps in the person-environment fit theory, in particular, relating to the supply-value fit or $S$-V fit. Firstly, previous research in $S$-V fit tended to look mainly at autonomy and supervision style. However, there appears to be no reported research that has simultaneously investigated in a single study, the effects of the discrepancy between the perceived and desired levels of work quantity, variety, power, responsibility and concentration required for the job. This study aims to fill that gap. This study examines the discrepancy between the supplies and values of work quantity, variety, power, responsibility and concentration, and its relationship with satisfaction at work. Secondly, the $S$-V fit theory has been relatively established in developed countries such as America and Britain. However it would be interesting to discover whether the theory is also applicable among civil service workers in a small isolated town, in a developing country such as Malaysia. Questionnaires were distributed and collected from one hundred respondents working in a government department in a small town of Gua Musang in Peninsular Malaysia. Support for the S-V fit theory was obtained, as results suggested that the greater the discrepancy between the supplies and values of work quantity, variety, power, responsibility and concentration required at work, the lesser was the satisfaction. The implication therefore was that if managers were desirous of improving satisfaction of their workers, they should ensure that their workers receive neither too much nor too little work variety, power, responsibility and concentration at work-for either state can result in lower satisfaction.
\end{abstract}

\begin{abstract}
ABSTRAK
Kajian ini bertujuan untuk mengisi dua jurang karya dalam teori "person-environment fit" terutama sekali "supply-value fit" atau "S-V fit". Yang pertama, kajian lepas telah mengkaji mengenai otonomi dan gaya penyeliaan. Walau bagaimanapun, tiada kajian sebelum ini yang mengkaji kesan perbezaan di antara persepsi dengan apa yang diidamkan, tentang kuantiti kerja, kepelbagaian kerja, kuasa, tanggungjawab dan tumpuan terhadap pekerjaan. Kajian ini bertujuan untuk memenuhi jurang tersebut. Kajian ini menganalisis tentang perbezaan antara "supplies" dan "values" dan hubungannya dengan kepuasan kerja. Yang kedua, teori " $S$ - $V$ " telah dikukuhkan di negara-negara maju seperti Amerika dan Britain. Walau bagaimanapun, adalah menarik jika kita dapat memastikan sama ada teori ini boleh digunakan di negara-negara membangun seperti Malaysia. Borang-borang soal selidik telah diedarkan dan dikutip daripada seratus responden yang bekerja di sebuah jabatan kerajaan di Gua Musang, iaitu sebuah pekan kecil di Malaysia. Sokongan untuk teori "S-V fit" telah menunjukkan di mana keputusan kajian mencadangkan lebih besar perbezaan antara "supplies" dan "work values", maka semakin kurang kepuasan kerja. Justeru itu, sekiranya pengurus ingin meningkatkan kepuasan kerja di kalangan pekerja-pekerjanya, beliau harus memastikan bahawa pekerjanya tidak dikehendaki mengendalikan pekerjaan yang terlalu banyak atau kurang kepelbagaian kerja, kuasa, tanggungjawab dan keperluan tumpuan terhadap pekerjaan. Akibat kekurangan atau berlebihan ciri- ciri tersebut adalah ketidakpuasan kerja.
\end{abstract}




\section{INTRODUCTION}

Parsons' (1909) seminal work appears to be the first to have stressed the importance of both person and environment variables in vocational choice. Today, both variables are regarded as important. However, somewhere in between these two periods (i.e. 1960's to 1990's), academics became divided. There were two extreme views. At one extreme, the view was that a person's behaviour was caused entirely by the "environment". At the other, the view was that the person's behaviour was determined solely by his "personality".

Mischel (1968) criticised the traditional trait theories for emphasising broad dispositions that manifest themselves stably and independently of stimulus conditions (Pervin 1989 \& Mischel, 1968) proposed that it is the environment that causes people to behave in a particular way and that this behaviour is situation specific. He argued that traditional trait theories such as Freud's (1938) psychoanalytic theory had generally overstated the case for behavioural consistency (Malim \& Birch, 1998). However, Mischel's objection seems to indicate that he did not acknowledge the true premise of trait theories. Trait theorists such as Cattell, and Eysenck did not suggest that personality always results in certain behaviour. Rather, they emphasise the interplay between multiple traits and environmental conditions, in the determination of specific behaviours Pervin (1989). Merahbian (1968) explained that the instinct-needhabit-trait-factor theories assume that :

\section{"similar situations are likely to elicit the same interpersonal behaviours, from the same individual, but not necessarily from different individu- als".}

There is therefore an assumption of within-individual consistency and between-individual variability in a given environment.

Sarason, Smith, and Diener, (1975) measured the percentage of the variance (differences in performance from one person to the next) accounted for by the situation and by the personality. Across a total of 138 experiments, the situation accounted on average for $10.3 \%$ and personality for $8.7 \%$ of the variance. In other words, neither variable (personality or the situation) was better able to predict behaviour than the other. Most personality psychologists now are interactionists in the sense that they emphasise both person and situation variables in predicting behaviour (Pervin, 1989). Several theorists (e.g. Bowers, 1973; Endler \& Edwards, 1978) have argued that it is fruitless to argue that either personality or the situation is all-important.

"Thus, both Mischel and Epstein, the
two major protagonists in the de-
bate, agreed that person and situa-
tion factors always enter into behav-
iour and that the relative amount of
consistency or variability will de-
pend on the persons, situations and
behaviours being considered... What
remains at issue is how much of each
there is and the kinds of person, situ-
ation and process units that should
be considered." (Pervin, 1989,
p.352).

This symbolises the resurgence of personenvironment fit. Osipow (1987) aptly summarises the problems associated with congruence in the following three main questions:

1. How do we assess people?

2. How do we measure their environment?

3. How do we compare the two regarding degree and quality of fit?

The essence of P-E fit was summarised by Edwards (1996) as follows:

"In essence, P-E fit embodies the
premise that attitudes, behaviour
and other individual level outcomes
result not from the person or envi-
ronment separately, but rather from
the relationship between the two
(Lewin, 1951; Murray, 1938; Pervin,
1989)". (p. 292) 
P-E fit is also of practical importance to managers. The environmental demands and person abilities fit underlies most models of personnel selection, in which the generally accepted paradigm is to analysis job demands, define abilities required to meet these demands and hire individuals with the requisite abilities (Schneider, 1978).

\section{LITERATURE REVIEW}

There is an abundance of research on P-E fit. Buboltz, Ebberwein, Watkins and Savickas (1995) discovered that in the last 20 years preceding their article, a total of 229 articles on P-E fit appeared in the Journal of Vocational Behavior and 75 articles on it appeared in the Career Development Quarterly. They also noted that, about 63 of the 229 articles on P-E fit in the Journal of Vocational Behavior and 22 out of the 75 in the Career Development Quarterly appear during the last five years preceding their article. In addition, there are other studies involving P-E fit (cited below) reported in other journals. This constitutes evidence that the subject matter of P-E fit has not only been well established and extensively researched, but also remains a current area of interest.

A review of the studies of P-E fit revealed that prior to 1987 , most studies did not distinguish between the different forms of fit and did not expressly state which category of fit they were investigating. According to Muchinsky and Monahan (1987), who appeared to be the first people to categories the different forms of fit, there are basically two categories of fit: complementary fit and supplementary fit. They summed up the core difference between the two as follows:

"An essential difference between the complementary and supplementary models is in the definition of the environment. The environment in the supplementary model is described according to the people who inhabit it. In the complementary model, the environment is defined apart from its inhabitants. Instead, it is described according to its demands and re- quirements, which are discerned, for example, in a work context through a job analysis. A person's abilities and characteristics are matched to the environment's (job's) needs. " ( $p$. 272)

Muchinsky \& Monahan (1987) explained that complementary fit, occurs when there is a "match between an individual's talents and the corresponding needs of the environment" (p. 268). By complementary, they meant that the "characteristics of an individual serve to make whole or complement the characteristics of an environment. The environment is seen as either deficient in or requiring a certain type of person in order to be effective" (p. 271). Supplementary fit, on the other hand, was said to exist when "a person fits into some environmental context because he or she supplements or embellishes or possesses characteristics which are similar to other individuals in this environment" (p. 268).

However Muchinsky \& Monahan's (1987) categorisation is still incomplete. They defined complementary fit as comprising only the environment demand and personal abilities fit (i.e. DA fit). There is another type of complementary fit that they failed to mention specifically. This is the fit between the "environmental supply" and the "personal value" (otherwise known as the "S-V fit"). Kristof (1996) expanded on Muchinsky and Monahan's (1987) definition to include S-V fit. In her article, she stated that there are two components of complementary fit. They are the Supply-Value fit (S-V fit) and the Demand-Abilities fit (D-A fit). Further explanation of the S-V and D-A fits follows:

- $\quad$ From the $\mathrm{S}-\mathrm{V}$ fit perspective, organisations supply financial, physical and psychological resources as well as the task-related, interpersonal and growth opportunities demanded and valued by employees (French, Caplan \& Harrison, 1982; Livingstone, Nelson \& Barr, 1997). Fit occurs when an organisation satisfies individuals' needs, desires or preferences (Kristof 1996).

- $\quad$ From the D-A fit perspective, organisations 
demand contributions from their employees in terms of their time, effort, commitment, knowledge, skills and abilities (French et al, 1982; Livingstone et al, 1997). Fit occurs when an individual has the abilities required to meet organisation demands (Kristof, 1996).
In short, D-A fit focuses primarily on meeting the needs of others, while S-V fit focuses primarily on meeting one's own needs (Caplan, 1987; Livingstone et al, 1997). Figure 1 taken from Kristof (1996) represents the relationship between S-V and D-A fit.

\section{Organisation}

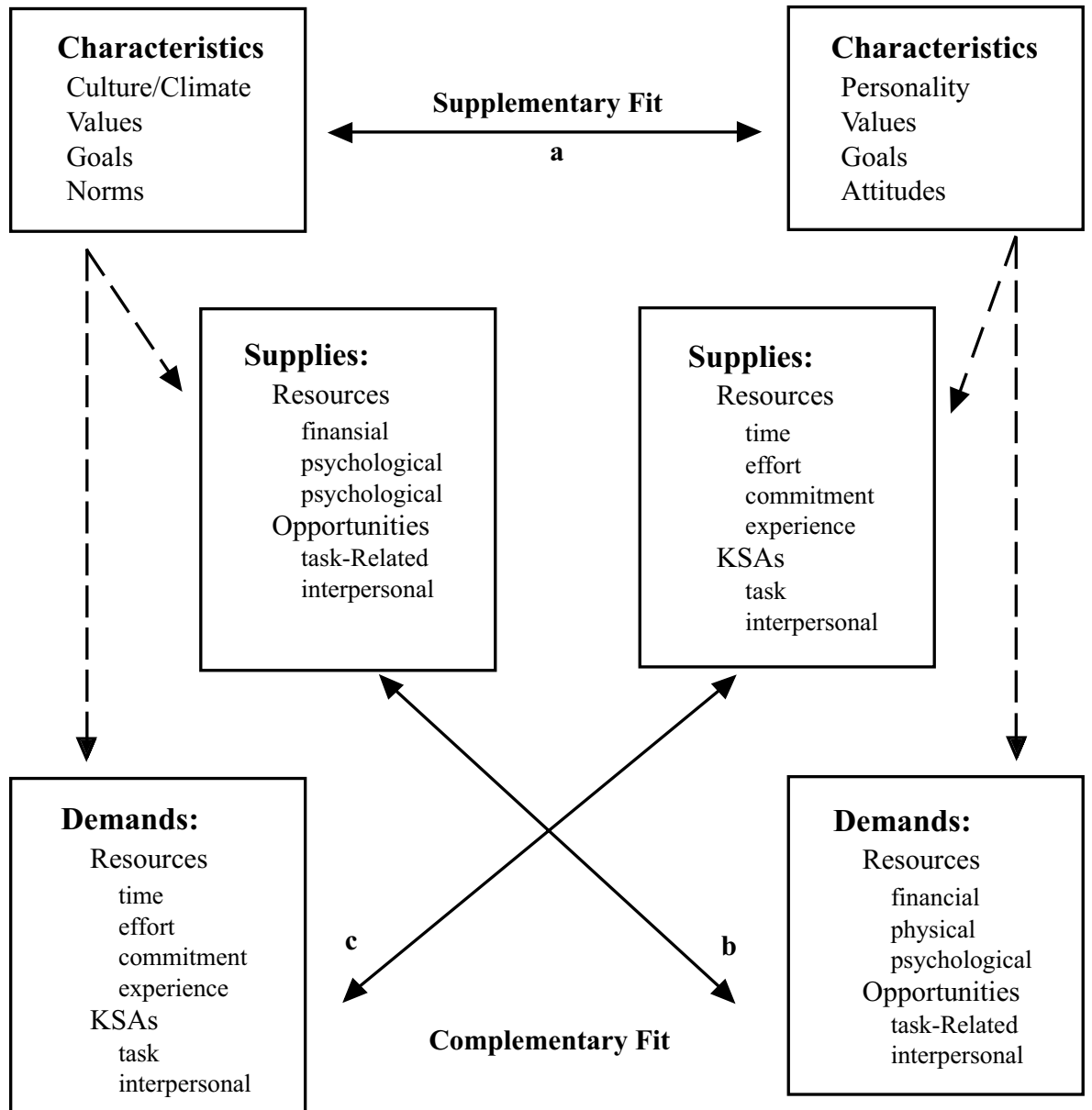

Figure 1

Various Conceptualisations of Person-Organisation Fit Source: Kristoff (1996) 
It can be seen from Figure 1 that $\mathrm{S}-\mathrm{V}$ and D-A fit are entirely different constructs. Previous researchers are often confused between S-V and D-A fit (Edwards \& Cooper, 1990; Livingstone et al. 1997). It is important to distinguish between them because in addition to their nature, they have also been shown to have different outcomes (Livingstone et al. 1997). S-V fit has been found to be related to dissatisfaction (Locke, 1969, 1976; Livingstone et al. 1997) whereas D-A fit has been found to be related to performance (Hackman \& Oldham, 1980; Naylor, Pritchard \& Ilgen, 1980; Porter \& Lawler, 1968; Livingstone et al. 1997). The confusion between S-V and D-A fit is evident in Mackowiak, Mackowiak and Schulz (1990). They expected to find a relationship between P-E fit and pharmacist job performance. They actually looked at S-V fit (they defined P-E fit as "the extent to which personal needs are supplied in the work environment") when in fact they should have examined D-A fit. Not surprisingly, they either found no relationship or a weak relationship between $\mathrm{S}-\mathrm{V}$ fit and performance. In view of this, the appropriate recommendation is that future research should examine job satisfaction rather than performance when using the $\mathrm{S}-\mathrm{V}$ fit model, and performance rather than job satisfaction when using the D-A fit model.

Another critical issue is that of the need for commensurability of scales that measure the person and the environment. Commensurate measurement is the measurement of both the person and environment with the same content dimensions and graded on the same scales. Examples of studies employing commensurate measures of the person and the environment are Edwards (1996) and French, Rogers and Cobb (1974). In addition to these studies, Caplan (1987) stressed the importance of measuring the person and the environment along commensurate dimensions. Caplan (1987) laid down three guidelines for operationalising fit:

- The person and the environment should be assessed along commensurate dimensions;

- The researcher must distinguish between objective and subjective measures of fit and its components;

- The researcher must be able to distinguish between "person abilities-environmental demands" and "person needs-environmental supplies".

Kristof (1996) indicated that some researchers have used direct measures of fit. This involves asking people explicitly whether they believe a good fit exists. Posner, Kouzes and Schmidt (1985) used such a method. In their study, managers directly rated how compatible their values were with those of their organisations and how often they had to compromise personal principles to meet organisational expectations. This method is plagued by the consistency bias (i.e., "I think that I fit well, so I must be satisfied with my job.") and is therefore not adopted in the current research. Edwards (1991) criticised direct measures primarily because they confound the constructs of the person and the environment, thereby preventing the estimation of their independent effects. In Edwards (1996), environmental supplies and personal values ( $\mathrm{S}-\mathrm{V}$ fit) are measured by asking respondents how much of each task is involved in their job and how much of each task they prefer. Livingstone et al. (1997) also conducted a study that employed a similar measure of S-V fit in their research. Respondents were asked two sets of questions with responses graded according to commensurate dimensions. Respondents were asked questions that measured the supplies in the organisation e.g. "People are rewarded for creative work in this organisation". They were also asked questions that measured their values for creativity. Questions that measure supplies and values for creativity are commensurate with each other. There are many other P-E fit studies like these. This method can be considered to be one of the popular ways of measuring P-E fit.

In another study by Roberts and Foti (1998), work structure was measured subjectively or perceptually. Work structure was treated as comprising job autonomy and supervisory structure. Job autonomy was measured with the autonomy subscale from the job diagnostic survey (JDS; Hackman \& Oldham, 1975). This dimension was measured using three items rated on seven-point scales. An example of the question is, "The job gives me considerable opportunity for independence and freedom in how I do the 
work" with answers ranging from "very accurate" to very inaccurate". Supervisory structure was measured with a modified form of the "Initiation of Structure" and "Tolerance of Freedom" subscales of the Leader Behavior Description Questionnaire (Form XII Stogdill, 1963). Each subscale consisted of ten items. A sample item from the Initiating Structure subscale is, "He or she encourages the use of uniform procedures". A sample item from the Tolerance of Freedom subscale is "He or she allows me complete freedom in my work". The answers for both these subscales were scored on five-point scales. It was found that satisfaction was higher for employees with high (low) self-leadership who worked in low (high) structure environments.

In a longitudinal study, Blau (1987) also used a subjective measure of the work environment - the perceived job scope. Perceived job scope was measured using a linear combination of four scales from the Job Characteristics Inventory (JCI; Sims, Szilagyi, \& Keller, 1976), namely skill variety, task identity, autonomy and feedback. Responses are rated on a 5-point scale ( $1=$ Very little, $5=$ Very much).

This study aims to fulfil two literature gaps. Firstly, the articles cited above tended to look mainly at autonomy and supervision style. However, there appears to be no reported study that has simultaneously investigated in a single study, the effects of the discrepancy between the perceived and desired levels of work quantity, variety, power, responsibility and concentration required for the job. This study aims to fill that gap. In addition, this study also examines the S-V fit i.e. the discrepancy between the supplies and values of work quantity, variety, power, responsibility and concentration, and its relationship with satisfaction. Since, the S-V fit theory has been relatively established in developed countries such as America and Britain, it would be interesting to discover whether the theory is also applicable at the other extreme situation, for example, in a small isolated town, in a developing country such as Malaysia. This would be the first step in determining the universal applicability of the personenvironment fit theory.

Finally, the construct of job satisfaction has been defined as a constellation of a person's attitudes toward or about a job as a whole. There are many theories of job satisfaction, some of which are now of historical interest e.g. Herzberg, Mausner, and Snyderman's (1959) Two-Factor theory. Some have not been well supported by empirical research (e.g. need comparison theories) and a few show promise of becoming major theories (e.g. high performance cycle and value theory) but relatively little work has been done to develop comprehensive theories of job satisfaction (Dipboye, Smith \& Howell, 1994). In conclusion, it can be said that there are considerable differences between theories of job satisfaction. The current research adopts the view of Smith, Kendall and Hulin (1969) that job satisfaction is made up of five separate facets. These facets are satisfaction with work, pay, promotion, supervision and co-workers.

From the literature review, it is possible to draw a theory in that, the more the perceived supplies differ from that of the desired level, the lower will be the satisfaction. This is so regardless of whether the supplies exceeded or were insufficient compared to the desired level. The alternative hypothesis accordingly is:

1a. The absolute difference scores (between perceived and desired work attributes) are negatively correlated with satisfaction.

\section{RESEARCH METHODOLOGY}

\section{Instruments}

Work congruence was measured using a questionnaire adapted from items in the Job Diagnostic Survey (JDS: Hackman \& Oldham, 1975). There were five items: quantity of work, variety of work, power, responsibility and amount of concentration required whilst doing the work. For each item, respondents were asked to indicate on a 9-point scale, how much of it was present in the job and how much they desired.

Job satisfaction was measured using the Job Descriptive Index (JDI; Smith Kendall \& Hulin, 1969). It consists of five separate sections. Each section measures one separate facet (the job it- 
self, pay, promotion, supervision, and co-workers). Total job satisfaction was measured by a simple total of the five facets. Smith Kendall and Hulin (1969) developed the JDI, which is a simple short questionnaire that requires low verbal measures and is suitable for a wide variety of situations. It was developed specifically to measure satisfaction with different job components or facets. The JDI uses 72 adjectives to describe the five dimensions of job satisfaction as follows:
i) Work (18 adjectives)
ii) Pay ( 9 adjectives)
iii) Promotion (9 adjectives)
iv) Supervision (18 adjectives)
v) Co-workers (18 adjectives)

Respondents were required to answer either "Yes", "No", or "?" for each adjective. The respondent was not asked how satisfied he/she was with his/ her work but rather to describe his/her work i.e. the responses are a job-referent rather than selfreferent.

Scoring for the questionnaire has been done in accordance with Smith et al's (1969) recommendation as follows:

- A positive answer to a positive item is scored 3

- A negative answer to a negative item is scored 3

- An undecided answer to any item is scored 1

A positive answer to a negative item is scored 0

A negative answer to a positive item is scored 0

Note: an undecided answer scores 1 point, not 2, because Smith et al. (1969) stated that a "?" is more indicative of dissatisfaction than satisfaction. This aspect was tested by Hanisch (1992) and was shown to be correct. The JDI has been reported to be the most frequently used measure of job satisfaction (De Meuse, 1986; O'Connor, Peters \& Gordon, 1978; Yeager, 1981; Ironson, Brannick, Smith, Gibson \& Paul, 1989). According to Ironson et al. (1989), the Social Science Citation Index and Psychological Abstracts revealed 454 articles referring to the JDI between January 1979 and November 1987. The JDI was shown to have dimensional consistency over a wide range of situations (Jung, Dalessio \& Johnson, 1986) and to have good discriminant and convergent validity. It has also been used in P-E fit studies to measure job satisfaction (Smart, Elton \& McLaughlin, 1986). It has been shown to be reliable and valid not only in America but also in Spain (Hulin, Drasgow \& Komocar, 1982), Saudi Arabia (Maghrabi \& Johnson, 1995), Hong Kong (Lam, 1995), Singapore (Goh, Koh \& Low, 1991) and Malaysia (Ahmad, 1996). The above-mentioned cases also demonstrate the ease of translating the JDI into different languages, as the items/questions on it are mostly one-word items.

The final section of the questionnaire measures the demographics of the respondents.

\section{Sample}

The entire sample consisted of managers, executives and non-executives in a government department in a small isolated town known as Gua Musang, in Peninsular Malaysia. One hundred and twenty questionnaires were distributed to all the workers who consisted mostly of non-executives, executives and a few managers. Only one hundred of the questionnaires returned were usable.

\section{RESULTS}

The cronbach coefficient alpha test of reliability was conducted on the congruence scale and the JDI. The figures were .68 and .89 respectively. Tests of correlation were done to see whether there were any significant relationships between the difference scores and satisfaction scores. 
Table 1

Correlation Between Difference Scores and Satisfaction Scores.

\begin{tabular}{|l|c|c|c|c|c|l|}
\hline & $\begin{array}{c}\text { Diff 1 } \\
\text { (quantity) }\end{array}$ & $\begin{array}{c}\text { Diff 2 } \\
\text { (variety) }\end{array}$ & $\begin{array}{c}\text { Diff 3 } \\
\text { (Power) }\end{array}$ & $\begin{array}{c}\text { Diff 4 } \\
\text { (Responsibility) }\end{array}$ & $\begin{array}{c}\text { Diff 5 } \\
\text { (Concentration) }\end{array}$ & $\begin{array}{l}\text { Diff } \\
\text { Total }\end{array}$ \\
\hline $\begin{array}{l}\text { Work } \\
\text { Satisfaction }\end{array}$ & -.134 & $-.223^{*}$ & $-.311^{* *}$ & $-.258^{* *}$ & $-.256^{* *}$ & $-.360^{* *}$ \\
\hline $\begin{array}{l}\text { Pay } \\
\text { Satisfaction }\end{array}$ & -.153 & -.142 & -.086 & $-.200^{* *}$ & $-.218^{*}$ & $-.227^{*}$ \\
\hline $\begin{array}{l}\text { Promotion } \\
\text { Sat }\end{array}$ & .114 & -.030 & $-.181^{*}$ & -.063 & -.046 & -.076 \\
\hline $\begin{array}{l}\text { Supervision } \\
\text { Sat }\end{array}$ & -.126 & -.171 & -.110 & -.138 & -.121 & $-.196^{*}$ \\
\hline $\begin{array}{l}\text { Co-worker } \\
\text { Sat }\end{array}$ & -.031 & -.148 & $-.266^{* *}$ & -.122 & $-.195^{*}$ & $-.239^{* *}$ \\
\hline \begin{tabular}{l} 
JDI Total \\
\hline
\end{tabular} & -.091 & $-.201 *$ & $-.272^{* *}$ & $-.204^{*}$ & $-.227^{*}$ & $-.304^{* *}$ \\
\hline
\end{tabular}

$\mathrm{N}=100$

"*” = significant at the .05 level

"*** = significant at the .01 level

Attention is drawn to Table 1. Support for the hypothesis was obtained in that the variable Diff Total was significantly negatively correlated with the JDI total (-.304 significant at the .01 level), i.e. the total (absolute) difference scores accounted for $9.2 \%$ of the variance in total job satisfaction. This suggests that the greater the difference between the perceived and desired work attributes (quantity, variety, power, responsibility and concentration required), the lower the satisfaction will be with the job as a whole. The variable of Diff Total is significantly negatively correlated with work satisfaction scores, pay satisfaction scores, supervision satisfaction scores and co-worker satisfaction scores (-.360 significant at the .01 level, -.227 and -.196 significant at the .05 level and -.239 significant at the .01 level respec- tively). This suggests that the greater the difference between the perceived and desired level totals, the lower the work satisfaction, will be pay satisfaction, supervision satisfaction and coworker satisfaction will be.

It can also be seen from Table 1 that the variable Diff 2 is significantly negatively correlated with work satisfaction scores and the JDI total (-.223 and -2.01 respectively, significant at the .05 level). This suggests that the greater the difference between the perceived and desired level of work variety, the lower the satisfaction will be with the work itself as well as satisfaction with the job as a whole. Also the variable Diff 3 is significantly negatively correlated with work satisfaction scores, co-worker satisfaction scores and the JDI total (-.311, -.266 and -.272 respectively, 
all significant at the .01 level). This suggests that the greater the difference between the perceived and desired level of power, the lower the satisfaction will be with the work itself, with the coworker, as well as with the job as a whole. The variable Diff 4 is significantly negatively correlated with work satisfaction scores, pay satisfaction scores and the JDI total (-.258, and -.200 significant at the .01 level, and -.204 significant at the .05 level). This suggests that the greater the difference between the perceived and desired level of responsibility, the lower the satisfaction will be with the work itself, satisfaction with the pay, as well as with the job as a whole. The variable Diff 5 is significantly negatively correlated with work satisfaction scores, pay satisfaction scores, co-worker scores and the JDI total (-.256 significant at the .01 level, -.218, -.195 and -.227, all significant at the .05 level). This suggests that the greater the difference between the perceived and desired level of concentration required for the job, the lower the satisfaction will be with the work itself, with the pay, with colleagues, as well as with the job as a whole.

\section{CONCLUSIONS AND DISCUSSION}

In this research, the discrepancy between the supplies and values for the various work attributes investigated were significantly negatively related to satisfaction at work, consistent with those found in developed countries. Consequently, this research is clearly significant as the person-environment fit theory (in particular the S-V Fit theory), propounded in developed countries such as America and Britain, was also found to be applicable in a small isolated town in a developing country such as Malaysia. In particular, when the difference scores for the various work attributes were combined they had a significant negative correlation with the total satisfaction scores. It is interesting to note that the correlation between the combined difference scores and satisfaction with the work itself was slightly higher at -.360 compared with the correlation between the combined difference scores and total job satisfaction at -.304. This is logical since the difference scores specifi- cally relate to aspects of work. Hence satisfaction with the work itself would be more affected by discrepancies between perceived and desired work attributes. Satisfaction with colleagues was also significantly negatively correlated with the total difference scores, although to a lesser extent. In particular, too much or too little power bestowed upon an individual, can have an unsettling effect on the relationship with colleagues.

In short, the results suggest that if managers are desirous of improving the satisfaction of their workers, they should ensure that their workers achieve better S-V fit. Managers should ensure that the workers be asked to perform work that is sufficiently varied - not too narrow in scope nor too varied for either state can result in lower overall satisfaction. The same goes for power, responsibility and the amount of concentration required at work.

Although the correlation between difference scores and total job satisfaction was only .304 , this is normal among P-E fit studies. This also suggests that there may be other aspects of $\mathrm{S}-\mathrm{V}$ fit that were not investigated such as the supplies and values for creativity, innovation and growth.

One limitation of this study is the small sample size. Perhaps future research should be conducted in similar isolated towns as well as cities within Malaysia. This can lend evidence towards the universal applicability of the personenvironment fit theory, at least as far as the relationship between perceptual fit and satisfaction is concerned. Another question that can be raised is, "Is fit always a good thing? It has been assumed that a high degree of fit is beneficial. However, could there be a dark side of fit? For instance, could there be situations where fit between a person and his work environment gives rise to negative outcomes? Kulik, Oldham \& Hackman (1987) answered this question by making a distinction between the two forms of fit (high growth needs and challenging jobs on the one hand and low growth needs and non-challenging work on the other). They pointed out that the outcomes for the two may be entirely different. Whereas high performance is anticipated from the first form of fit, it is not expected from the second form. However, high job satisfaction may be an outcome from 
the second form of fit. In the context of the current research, workers who prefer and were involved in work that was of low quantity, variety, power, responsibility and concentration, may be satisfied but could not properly be considered to be high performers.

\section{REFERENCES}

Ahmad, K. Z. B. (1996). A comparative study of job satisfaction prior to and after the implementation of the new remuneration scheme in EPF. Unpublished MBA Dissertation. University of Malaya library.

Blau, G. J. (1987). Using a person-environment fit model to predict job involvement and organisational commitment. Journal of Vocational Behavior, 30, 240-257.

Bowers, K. (1973). Situations in psychology: an analysis and critique. Psychological Review, 80, 307-36.

Buboltz, W. C., Ebberwein, C., Watkins, C. E., \& Savickas, M. L. (1995). A comparison of the content, authors and institutions represented in the Career Development Quarterly and the Journal of Vocational Behaviour. Journal of Vocational Behavior, 46, 216-226.

Caplan, R. D. (1987). Person-environment fit theory and organizations: commensurate dimensions, time perspectives, and mechanisms. Journal of Vocational Behavior, 31, 248-267.

De Meuse, K.P. (1986). A compendium of frequently used measures in industrial / organizational psychology. The Industrial-Organizational Psychologist, 23, (2), 53-59.

Dipboye, R. L., Smith, C. S., \& Howell, W. C. (1994). Understanding Industrial and Organizational Psychology. Orlando, Florida: Harcourt Brace \& Company.
Edwards, J. R. (1996). An examination of competing versions of the person-environment fit approach to stress. Academy of Management Journal, 39, 292 - 339.

Edwards, J. R. (1991). Person-job fit: a conceptual integration, literature review and methodological critique. International Review of Industrial/ Organizational Psychology, 6, 283-357.

Edwards, J. R. \& Cooper, C. L. (1990). The person-environment fit approach to stress: recurring problems and some suggested solutions. Journal of Organizational Behavior, 11, 293 $-307$.

Endler, N. S., \& Edwards, J. (1978). Person by treatment interactions in personality research. In L.A. Pervin \& M. Lewis (Eds.), Perspectives in Interactional Psychology. New York: Plenum.

French, J. R. P., Caplan, R. D. \& Harrison, R. V. (1982). The Mechanisms of Job Stress and Strain. London: John Wiley \& Sons.

French, J. R. P. Jr., Rogers, W., \& Cobb, S. (1974). Adjustment as person-environment fit. In G.V. Coelho, D.A. Hamburg, \& J.E. Adams (Eds.), Coping and Adaptation. New York: Basic Books.

Freud, S. (1938). The Basic Writings of Sigmund Freud. New York: Modern Library.

Goh, C. T., Koh, H. C., \& Low, C. K. (1991). Gender effects on the job-satisfaction of accountants in Singapore. Work and Stress, 5, (4), 341-348.

Hackman, J. \& Oldham, G. R. (1975). Development of the job diagnostic survey. Journal of Applied Psychology, 60, (2), 159-170.

Hackman, J. R. \& Oldham, G. R. (1980). Work Redesign. Reading, MA: Addison-Wesley. 
Hanisch, K. A. (1992.) The Job Descriptive Index revisited: questions about the question mark. Journal of Applied Psychology, 77, (3), 377-382.

Herzberg, F., Mausner, B. \& Snyderman, B. (1959). The Motivation to Work. New York: John Wiley \& Sons.

Hulin, C. L., Drasgow, F., \& Komocar, J. (1982). Applications of item response theory to analysis of attitude scale translations. Journal of Applied Psychology, 67, (6), 818-825.

Ironson, G. H., Brannick, M. T., Smith, P.C., Gibson, W. M., \& Paul, K. B. (1989). Construction of a job in general scale: comparison of global, composite and specific measures. Journal of Applied Psychology, 74, (2), 193-200.

Jung, K. G., Dalessio, A. \& Johnson, S. M. (1986). Stability of the factor structure of the Job Descriptive Index. Academy of Management Journal, 29, 3, 609-616.

Kristof, A. (1996). Person-organisation fit: an integrative review ofits conceptuali-sations, measurement, and implications. Personnel Psychology, 49, 1-49.

Kulik, C. T., Oldham, G. R. \& Hackman, J. R. (1987). Work design as an approach to person-environment fit. Journal of Vocational Behavior, 31, 297-318.

Lam, S. K. (1995). International Journal of Management, 12, (1), 96-101.

Lewin, K. (1951). Field Theory in Social Science. New York: Harper.

Livingstone, L. P., Nelson, D. L. \& Barr, S. H. (1997). Person - environment fit and creativity: an examination of supply - value and demand - ability versions of fit. Journal of Management, 23, (2), 119-146.
Locke, E. A. (1969). What is job satisfaction? Organizational Behavior and Human Performance, 4, 309-336.

Locke, E. A. (1976). The nature and causes of job satisfaction. In Handbook of Industrial and Organizational Psychology. (ed. Dunnette, M. D.), Skokie, IL: Rand McNally.

Mackowiak, J.I., Mackowiak, L. R. \& Schulz, R. M. (1990). Person-environment fit as a predictor of hospital pharmacist job performance. American Journal of Hospital Pharmacy, 47, 1089-1095.

Maghrabi, A.S. \& Johnson, D.A. (1995). An Arabic version of the revised Job Descriptive Index. Current Psychology, 14, (1), 47-53.

Malim, T. \& Birch, A. (1998). Introductory Psychology. London: MacMillan Press Ltd.

Merahbian, A. (1968). An Analysis of Personality Theories. New Jersey: Prentice Hall.

Mischel, W. (1968). Personality and Assessment. New York: John Wiley \& Sons.

Muchinsky, P. M. \& Monohan, C. J. (1987). What is person-environment congruence? supplementary versus complementary models of fit. Journal of Vocational Behavior, 31, 268-277.

Murray, H. A. (1938). Explorations in Personality. Boston: Houghton Mifflin.

Naylor, J. C., Pritchard, R. D. \& Ilgen, D. R. (1980). A Theory of Behavior in Organizations. New York: Academic Press.

O'connor, E. J., Peters, L. H. \& Gordon, S. M. (1978). The measurement of job satisfaction: current practices and future considerations. Journal of Management, 4, 17-26.

Osipow, S.H.(1987). Applying person-environment theory to vocational behavior. Journal of Vocational Behavior, 31, 333-336. 
Parsons, F. (1909). Choosing a Vocation. Boston, MA: Houghton Mifflin.

Pervin, L. A. (1989). Persons, situations, interactions: the history and a discussion of theoretical models. Academy of Management Review, 14, (3), 350-360.

Porter, L.W. \& Lawler, E.E. (1968). Managerial Attitudes and Performance. Homewood, IL: Dorsey Press.

Posner, B. Z., Kouzes, J. M. \& Schmidt, W. H. (1985). Shared values make a difference an empirical test of corporate culture. Human Resources Management, 24, (3), 293-309.

Roberts, H.E. \& Foti, R.J. (1998). Evaluating the interaction between self-leadership and work structure in predicting job satisfaction. Journal of Business and Psychology, 12, (3), 257267.

Sarason, I.G., Smith, R.E. \& Diener, E. (1975). Personality research: components of variance attributable to the person and the situation. Journal of Personality and Social Psychology, 32, 199-204.
Schneider, B. (1978). Person-situation selection: a review of some ability-situation interaction research. Personnel Psychology, 31, 281-297.

Sims, H., Szilagyi, A. \& Keller, R. (1976). The measurement of job characteristics. Academy of Management Journal, 19, 195-212.

Smart, J. C., Elton, C. F. \& Mclaughlin, G. W. (1986). Journal of Vocational Behavior, 29, 216-225.

Smith, P.C., Kendall, L.M. \& Hulin, C. L. (1969). The Measurement of Satisfaction in Work and Retirement: A Strategy for the Study of Attitudes. Chicago: Rand McNally \& Company.

Stogdill, R. M. (1963). Manual for the Leader Behavior Description Questionnaire - Form XII. Columbus: Bureau of Business Research, The Ohio State University.

Yeager, S.J. (1981). Dimensionality of the Job Descriptive Index. Academy of Management Journal, 24, 205-212. 